\title{
A Proposed Training Program for Developing Reciprocal Teaching Skills For Secondary School English Language Teachers
}

A research derived from a master thesis at the Department of

Curricula and Teaching Methods.College of Education,

Ahmed Awad Ali Asiri

King Khalid University

Educational supervisor at the Ministry of Education,

Kingdom of Saudi Arabia

\section{Dr. Ahmed Atif Alshehri}

Associate professor at the Department of Curricula and Teaching Methods. College of Education, King Khalid University

Abstract:

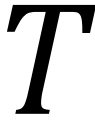

his research aims to prepare a proposed training program for developing reciprocal teaching skills for secondary school English language teachers. To achieve this goal, the researcher prepared a list of reciprocal teaching skills. In the light of this a questionnaire was prepared to identify the training needs of English language teachers at secondary school and their level of the 315 English language teachers in the secondary school which affiliate to the department of education in Asseer Region. The researcher used the descriptive approach in preparing the research tool. The results of research resulted in a list of training needs in the light of reciprocal teaching skills for secondary school English language teachers and were generally high level of need. Accordingly, a proposed training program was prepared to develop the reciprocal teaching skills of secondary school English language teachers.

Keywords: Training Program, Reciprocal Teaching Skills, English Language Teachers.

\section{Introduction:}

There is no doubt that the world, today, witnesses many changes in various areas of life, one of the most important of these areas is"public education institutions"; since education is a process that 
constantly evolving through knowledge and technological progress in research and studies, and this is what make education keep pace with these changes, and face these challenges which stand in front of progress,by improving and developing the educational process.

It is not possible to talk about educational reform in isolation from teacher reform, because the future teacher accounts for a large area in this issue, as the teacher is one of the basic components of the future system.The educational curricula, whatever quality, lose value at the hands of an unskilled teacher. Consequently,"teacher development"has the attention of educational institutions at all levels; due to the importance role the teacher plays in the educational process, and because the teacher represents the main element in any educational system, and the active power in the educational system. Hence, this issue became a basic input for educational reform (Al-Mady, 2013).

Some recent trends have emerged in the field of teacher preparation, which emphasizes the need to keep up with these changes, and pursue scientific, educational and technical developments, and perhaps the most important of these trends is that which emphasizes the preparation of the teacher and his qualification in accordance with professional standards and requirements, which help to perform his roles and carry out his duties at the fullest extent, in order to keep pace "age developments" and dealing with future challenges (Al-Mady, 2013).

Studies such as Al-Jeaid (2008) and Qadi (2014) also called for "teacher development" in order to keep 
pace with the demands of the modern era, considering that the teacher will remain an essential element in the educational process, and the educational system will not be able to face challenges of contemporary globalization without giving the teacher the priority of care and attention, in all stages "selection, preparation, and training", with the aim of raising teacher's level, and helping him achieve the necessary interaction and adaptation to contemporary developments.

(Al-Sayegh, 2002) study found that the teacher preparation and training programs in the Kingdom of Saudi Arabia suffer from shortcomings and weaknesses, and they need to be developed and improved to fit the modern era and multiculturalism.

The issue of teacher development in general, and the development of the English language teacher in particular, received the attention of the educational policy in the Kingdom in an attempt to bridge the gap between performance and skill, and work to develop teacher's skills continuously during service through training programs. The studies have also emphasized the importance of developing English language teacher, and determiningthe teaching performance level, and meeting his training needs, one of these studiesis "Alharby study" (2012).

Consequently, there is an ongoing need to raise the effectiveness of teaching and the efficiency of learning situations for English language teachers in this rapidly developing world in the cognitive and technological aspects, which requires that teaching development processes has to go hand in hand with developments in the field of educational research (Ministry of Education, 2003). 
On search for a modern teaching method, the reciprocal teaching strategy emerges as one of the metacognitive strategies that depends on learning based the principle of positivity and interaction; so that the learner engages in a number of activities through which he acquires information, concepts and skills in a targeted and functional manner, which leads to the achievement of a meaningful learning (Sulaiman, 2010).

Reciprocal teaching strategy is considered one of the modern teaching strategies, and an educational thought based on designing educational situations in the form of co-operative groups interacting with the teacher and with each other, under the supervision and guidance of the teacher leading the learner to become a thinker and interacting with problemsolving(Bayoumi, 2011).

Reciprocal teaching strategy is, also, one of the important strategies in teaching the English language, because it improves the linguistic skills of learners and improves the level of speaking and listening. It also develops deep reading comprehension, captures meaning from a written text, and enhances the level of discussion among learners. Studies that have focused on the use of reciprocal teaching in teaching English language include (Shahhosseini, 2011) and (Sun, L, 2010) that showed the effectiveness of this strategy in teaching English language.

Based on the importance of reciprocal teaching strategy in teaching the English language, and based on the role of training needs in determining the required knowledge and skills to provide the trainees with, this research sought to design a training program for developing reciprocal teaching skills for secondary school English language teachers. 


\section{Problem of the research:}

The feeling of the problem stems from the researcher's work as a teacher of English at secondary school and his teaching of English language courses for a period of more than five years, where the researcher noticed that there are deficiencies in the training programs for English language teachers dealing with modern teaching strategies.

This was confirmed by previous studies that indicated the importance of developing an English teacher and training him in modern teaching methods in order to be in line with modern-day variables such as Al-harby Study (2012) which addresses identifying the training needs of English language teachers in the field of foreign language teaching, and (Kusoumoto, 2009) that revealed the training needs of English language teachers for modern teaching methods.

The importance of the strategy is also clarified through the researcher's use at secondary school, showing its effectiveness and relevance in teaching English to students and its positive results. The studies also confirmed the importance of reciprocal teaching such as Al-Yasiri (2013), which aimed to examine the effect of reciprocal teaching strategy in developing language skill.

In light of what has mentioned above, and what previous studies and research have emphasized on the importance of developing the English language teacher and training him in modern teaching methods, and a desire of the researcher to contribute in developing the English language teaching skills of teachers through training programs. The current research seeks to design a training program for developing reciprocal teaching skills for secondary school English language teachers. 


\section{Questions of the research:}

The research seeks to answer the following questions:

- What are the training needs based reciprocal teaching for secondary school teachers of English in Asseer?

- What is the proposed training program based reciprocal teaching for secondary school teachers of English in Asseer?

\section{Objectives of the research:}

The researcher aims to determine training needs based reciprocal teaching for secondary school teachers of English, and to propose a training program based reciprocal teaching for secondary school teachers of English in Asseer.

\section{Importanceof the research:}

The importance of the current research lies in supporting the English language teacher recognizes reciprocal teaching strategy that enables him to develop his performance, and to develop his teaching skills. In addition to proposing a training program aimed at meeting the training needs of English language teachers at secondary school in the light of reciprocal teaching skills.

\section{Terminology of the study:}

\section{The training program:}

Al-gamal(2017) defined it as "All educational and instructional experiences that are presented in the light of an organized and proposed educational plan that includes objectives, content, methods of teaching and evaluation, and aims to provide workers with teaching skills" (p. 9). The researcher defines it procedurally as: An organized and intended activity that aims at 
developing English language teachers's knowledge and improving their teaching skills in the English language subject duringa specific time period.

\section{- Reciprocal Teaching:}

Zaitoun (2003) defined it as "An educational activity that takes the form of a dialogue between teachers and students, or between students with each other, so that they exchange roles according to the sub-strategies included (prediction - questioning - clarification summarization) in order to understand a writtentext, and to control this understanding through monitoring " (p. 224). The researcher defines it procedurally as:"An educational activity based a positive dialogue between the teacher of English and the student, and between students with each other towards learning the English language using the stages involved (prediction, questioning, clarification, and summarization).

\section{Theoretical framework}

Firstly: Reciprocal Teaching

\section{(A): Advantages of reciprocal teaching:}

Reciprocal teaching has several advantages, andthe most important of these advantages according to (Zaitoun, 2003; Iindblom, 2000) are:

- Improving academic achievement of students.

- Arousing students 'previous experiences.

- Developing the skill of dialogue and discussion.

- Raising the level of deep understanding among students.

- Helping students gain the following skills:"prediction, questioning, clarification, and summarization".

- Developing social skills.

- Improving the teaching and learning process by generating motivation. 
- It can be used in accumulated classes.

(B): The importance of reciprocal teaching

Studies and research agree on the importance of reciprocal teaching, such as the study of Al-Shuaibi (2006) and Al-Muntashiri (2008). The importance of reciprocal teaching can be summarized as follows:

- Depends on cooperative learning, which leads to providing the appropriate atmosphere for education.

- Based on student work through groups, each student plays a role in the group to which he belongs.

- It works to reduce the teacher's effort and his students on the one hand, and the effort made by the students with each other on the other hand in order to achieve the goal of the lesson.

- Ease of application in different classes and in most subjects.

- Develops the ability for discussion.

- Developsstudents' ability topredict events.

- Increase students' motivation towards learning.

- Spread fun and joy among students.

- Develops students' ability to summarize.

- Develops students' ability to ask questions.

- Enable Students to gain the skill of eliciting important information from the presented text.

(C): Teacher's role in reciprocal teaching strategy

The teacher has several roles to perform during reciprocal teaching, (Sulaiman, 2010) mentioned these roles as follows:

- Modeling the four full stages at the beginning of the lesson, then gradually decreasing his role to pass to the students.

- Organizing the classroom environment and dividing students into heterogeneous cooperative groups.

- Distribution students into (leader - summarizer questioner - clarifier - predictor). 
- Explaining the lesson objectives to students to know what is expected of them.

- Distributing tasks and activity cards to students.

- Directing students to cooperate and participate in all tasks and activities and not to keep any information to themselves because the final score is for everyone.

- Monitoring ongoing conversations and discussions within groups.

- Intervening to facilitate learning when needed.

- Allocating a suitable time to perform the tasks of each paragraph according to its length and degree of difficulty.

second: educational training for in-service teachers:

(A) Definition of educational training for in-service teachers:

Al-Saeed and Saleh (2008) defined in-service teacher training as "A set of experiences that are prepared for teachers in order to develop their competencies and to perform their work better, which helps in achieving training goals or the curricula they are teaching "(p. 10).

Tohri (2016) defines it as "A structured and preplanned process, aimed at developing the professional competencies of teachers and improving their job performance, by providing a set of strategies, activities, information and skills that are carried out according to specific criteria" (p. 34).

(B) The importance of educational training for teachers during service

The importance of educational training for teachers according toAbd al-Samea and others (2005) is:

- Instructors acquire knowledge, skills, and attitudes directly related to work, which develops their roles. 
- The learner gains self-confidence, and the ability to work independently.

- Training, as a planned and organized effort, helps improving the current and future performance of learners and groups alike.

- Training contributes to reducing mistakes; as a welltrained teacher reduces his mistakes.

- The trainee acquires new experiences that qualify him to assume greater responsibilities, and may be leadership responsibilities.

- Training develops the learner's flexibility and ability to adapt in his working life.

- Through training, expenses can be reduced. Increasing skills and competencies leads to a decrease in the percentage of errors in work.

(C): Goals of educational training for in-service teachers Educational training has several motives for inservice teachers, (Al-Zayyan, 2013) refers to these goals and motives are as follows:

- Those who join the work for the first time are provided -only- with the theoretical information about that work, So they arein need to a special training in order to raise their level and acquire new skills and knowledge that qualify them to perform work better.

- The process of rapid development in science and technology, in addition to the emergence of new technological means needed training order to be able to use them properly in order to adapt to work.

- Increasing the effectiveness of the teacher, and providing him with the best methods and the latest educational theories that help him in performing his duties.

- Treating deficiencies for those who did not receive a good preparation before enrolling in the teaching profession. 
(D): Obstacles in educational training for in-service teachers

Educational training faces some obstacles that limit its success in educational institutions. Regional Office for the Arab World, 2000) listed the obstacles of educational training as follows:

- The disruption of educational policies and the inconvenience of imported and quoted templates to the national circumstances in Arab societies.

- The programs are based on an improvised and descriptive diagnosis, and not on a thorough analysis of the special nature of the educational system and economic reality.

- The absence of an effective organization that adapts the curriculum and prepares teachers to inform the continuous needs of society.

- Lack clarity of goals, or their inadequacy so that there is no clear answer if we ask about what human we want to achieve an appropriate amount of education, and what will be his role in society, and whether the teacher is able to make a difference in society.

- Is the training based on a proper link between thought and work, that is, between theory and practice.

The third dimension: training needs: Definition, importance, characteristics, types, ways of determining:

First: Definition of training needs

Al-Lokani and Al-Jamal (2013) defined the training needs as "A set of changes and developments that must be achieved in teachers' information, skills, and directions to make them able to perform their educational work, and to improve the level of their job performance, which in turn contributes to improving the quality of learning" (p. 10). 
Abu al-Hasan (2016) defines it as "the knowledge, skill, and attitudes that must be developed in learner's behavior or providing it to the teacher, with the aim of improving performance, increasing productivity, or developing a specific behavior, as it is the difference between the actual reality of teacher performance and the desired reality" (p. 65).

\section{Second: The importance of identifying training needs}

Al-Dahshan (2017) stated the importance of identifying training needs, as follows:

- The determination of training needs is the basis for all the elements of the training process, designing the content and activities of the training program, and evaluating training programs. Identifying training needs is an indicator that guides training in the correct direction of these sub-processes.

- Identifying training needs helps to focus on good performance and the primary goal of training.

- Identifying training needs clarifies the learners to be trained, the type of training required, and the expected results from them.

- Wasting time, effort and money in the absence of identifying training needs or inaccurately identifying them.

\section{Third: Designing educational training programs for} teachers during service

The importance of designing training programs is to achieve the training goals, as it is an effective activity through which the training needs are fulfilled, as it is the main entrance to the process of designing a training plan that is designed based on the revealed training needs (Abbas, 2007). The training program is the tool that links the training needs, the goals required of the program, resources, methods, and training topics with each other in a regular relational manner, and this is 
what the training program design process is based on. If we follow the steps and procedures that follow this design process, we would realize that there is agreement between books and scholars, which Qashtan (2007) summarized as follows:

- Determining the objectives of the training program.

- Defining the topics of the training program.

- Determining methods, aids, and techniques appropriate for training.

- Determining the appropriate place for training.

- Selecting the participants in the program, and the standards that must be met for them to join it.

- selecting competent trainers.

- Preparing the training budget.

- Determining the evaluation tools, their types and times, methods of analyzing, and employing their results.

\section{Procedures of the research:}

Methodology of the research:

The research employed the analytical descriptive method through which training needs for secondary school teachers of English are identified in light of reciprocal teaching skills, and then analyzed, to identify training needs for research and to design the proposed training program in light of them.

\section{Population and participants of the research:}

Population of the current study consists of all English language teachers at secondary school in Asseerregion. participantswere (315) teachers of English language at secondary school in Asseer region.

\section{Tools of the research:}

Based on the nature of the data, and based on the method used in the study, a questionnaire was designed to determine the training needs of secondary school 
English language teachers in light of reciprocal teaching skills according to the following steps:

\section{Building the Tool:}

The study tool was built with reference to literature and previous studies related to the subject of the study. The study tool consisted -in its final form- of two parts: first: It deals with participants' primary data such as: academic qualification, type of educational qualification, number of years of experience. second: It consists of (45) items dealing with the training needs based reciprocal teaching among teachers of English language. They are distributed on three dimensions. The first: It deals with the training needs related to lesson planning, and it consists of (13) items. The second: It deals with the training needs related to implementation of the lesson, and it consists of (23) items. The third: It deals with training needs related to evaluation, and it consists of (9) items.

\section{Validity of the study tool:}

\section{Face validity (validity of Jury):}

After designing the study tool, which deals with "A Proposed Training Program for Developing Reciprocal Teaching Skills For Secondary School English Language Teachers", it was presented to a number of jury in order to guide their views. The jurywere kindly asked to express their opinion about"items clarity" and the relevance of what they were designed for, and suitability of the items for the dimension to which they belong. Modifications and suggestions through which the questionnaire can be developed were taken into consideration.

\section{Internal consistency validity:}

The researcher applied the questionnaireto to an exploratory sample consisting of (315) teacher. Using 
the sample data, the researcher calculated the Pearson correlation of coefficient to measure the internal validity of the questionnaire. The correlation coefficient was calculated between the degree of each item by the total degree of the dimension that the item belongs to, as shown in the following tables.

Table (1): Pearson correlation of coefficients for items (training needs based reciprocal teaching among English language teachers) with dimensiontotal score

\begin{tabular}{|c|c|c|c|c|c|c|c|}
\hline \multicolumn{2}{|c|}{$\begin{array}{l}\text { Lesson planning } \\
\text { skills }\end{array}$} & \multicolumn{4}{|c|}{ Lesson implementation skills } & \multicolumn{2}{|c|}{ Evaluation skills } \\
\hline Item & $\begin{array}{c}\text { Correlation } \\
\text { coefficient }\end{array}$ & Item & $\begin{array}{l}\text { Correlation } \\
\text { coefficient }\end{array}$ & Item & $\begin{array}{l}\text { Correlation } \\
\text { coefficient }\end{array}$ & Item & $\begin{array}{l}\text { Correlation } \\
\text { coefficient }\end{array}$ \\
\hline 1 & $0.625 * *$ & 1 & $0.664 * *$ & 14 & $0.772 * *$ & 1 & $0.744 * *$ \\
\hline 2 & $0.701 * *$ & 2 & $0.673^{* *}$ & 15 & $0.587^{* *}$ & 2 & $0.615 * *$ \\
\hline 3 & $0.708^{* *}$ & 3 & $0.575 * *$ & 16 & $0.758 * *$ & 3 & $0.709 * *$ \\
\hline 4 & $0.595^{* *}$ & 4 & $0.634^{* *}$ & 17 & $0.670^{* *}$ & 4 & $0.661^{* *}$ \\
\hline 5 & $0.602 * *$ & 5 & $0.717^{* *}$ & 18 & $0.502^{* *}$ & 5 & $0.490^{* *}$ \\
\hline 6 & $0.622 * *$ & 6 & $0.560 * *$ & 19 & $0.731 * *$ & 6 & $0.524^{* *}$ \\
\hline 7 & $0.652 * *$ & 7 & $0.501 * *$ & 20 & $0.469 * *$ & 7 & $0.575 * *$ \\
\hline 8 & $0.731^{* *}$ & 8 & $0.792^{* *}$ & 21 & $0.554 * *$ & 8 & $0.466 * *$ \\
\hline 9 & $0.691 * *$ & 9 & $0.694^{* *}$ & 22 & $0.524^{* *}$ & 9 & $0.629 * *$ \\
\hline 10 & $0.698^{* *}$ & 10 & $0.746^{* *}$ & 23 & $0.544^{* *}$ & - & - \\
\hline 11 & $0.499^{* *}$ & 11 & $0.759^{* *}$ & - & - & - & - \\
\hline 12 & $0.590 * *$ & 12 & $0.642^{* *}$ & - & - & - & - \\
\hline 13 & $0.698 * *$ & 13 & $0.647^{* *}$ & - & - & - & - \\
\hline
\end{tabular}

** Significant at the level of $\mathbf{0 . 0 1}$

Table (1) clarifies that all dimensionitems are significant at the level of (0.01), where correlation of coefficients values for the dimension"lesson planning skills" ranged between $(0.499,0.731)$, and for the dimension"lesson implementation skills" between $(0.496,0.792)$, and for the dimension "Evaluation skills" between $(0.466,0.744)$, all of which are accepted correlation coefficients, and this is an indication of high coherence coefficients, as it indicates high and sufficient validity indicators that can be trusted in the application of the current study tool.

Table (2) clarifies that all dimensions are significant at the level of (0.01), where the values of correlation coefficients for the dimensions ranged between $[0.791$ 
and 0.907), which are accepted correlation coefficients, and this is an indication of high coherence coefficients, as it indicates high and sufficient validity indicators that can be trusted in the application of the current study tool.

Table (2) Pearson correlation of coefficients for the dimensionitems (training needs based on reciprocal teaching among English language teachers) with the dimension total score

\begin{tabular}{|c|c|}
\hline Dimension & Correlation of coefficient \\
\hline lesson planning skills & $0.847^{* *}$ \\
\hline lesson implementation skills & $0.907^{* *}$ \\
\hline Evaluation skills & $0.791^{* *}$ \\
\hline
\end{tabular}

** Significant at the level of 0.01

(C)Reliability of the study tool:

The researcher calculated reliability using Cronbach'sAlpha reliabilitycoefficient, Table (3) shows reliability coefficient for the dimensions of the study tool, as follows:

Table (3) Cronbach's Alphafor reliability of the study tool

\begin{tabular}{|c|c|c|c|}
\hline $\mathbf{N}$ & Dimension & Number of items & Reliability coefficient \\
\hline 1 & lesson planning skills & 13 & 0.939 \\
\hline 2 & lesson implementation skills & 23 & 0.953 \\
\hline 3 & Evaluation skills & 9 & 0.904 \\
\hline \multicolumn{2}{r}{ Total reliability } & 45 & 0.966 \\
\hline
\end{tabular}

Table (3) clarifies that the study questionnaire has a statistically acceptable reliability, where the value of the total reliability coefficient (alpha) reached (0.966) which is a high degree of reliability, as the consistency coefficients of the study tool ranged between $(0.904$ and 0.953 ) which indicate high reliability indicators that can be trusted in the application of the current study tool.

\section{Statistical methods used in the current study:}

A number of appropriate statistical methods were used using the Statistical Package for SocialSciences which is denoted by the abbreviation (SPSS), then the following statistical methods were calculated: 
- Frequencies and percentages to identify the functional characteristics of participants.

- Pearson Correlation coefficient to calculate the validity of the internal consistency of the study tool.

- Cronbach's Alpha to calculate the reliability coefficient of the different dimensions of the study tool.

- "Mean"to know to what extent responses of participants are high or low than the main dimensions (items averages). Taking into consideration that it is useful in arranging dimensions according to the highest mean.

- "Standard Deviation" was calculated to identify the extent to which participants' responses to each item deviated from the study variables items, and for each of the main dimensions of their mean. It is notable that the standard deviation clarifies the dispersion in participants' responses for each of the items of the study variables, in addition to the main dimensions. The closer value from zero, the responses focus and the dispersion decreases in the questionnaire.

\section{Results, Explanation and Discussion:}

What are the training needs based reciprocal teaching for secondary school teachers of English in Asseer?

Frequencies, percentages, means, and standard deviation of participants' responses were calculated to determine the training needs based reciprocal teaching for secondary school teachers of English in Asseer

Table (4) Means, and standard deviation ofparticipants' responses about the training needs based reciprocal teaching for secondary school teachers of English in Asseer

\begin{tabular}{|c|c|c|c|c|}
\hline $\mathbf{N}$ & Reciprocal teaching skills & Mean & Standard Deviation & Rank \\
\hline $\mathbf{1}$ & lesson planning skills & $\mathbf{3 . 6 0}$ & $\mathbf{0 . 7 3}$ & $\mathbf{1}$ \\
\hline $\mathbf{2}$ & lesson implementation skills & $\mathbf{3 . 5 2}$ & $\mathbf{0 . 7 5}$ & $\mathbf{2}$ \\
\hline $\mathbf{3}$ & Evaluation skills & $\mathbf{3 . 5 2}$ & $\mathbf{0 . 7 7}$ & $\mathbf{3}$ \\
\hline \multicolumn{2}{|c|}{ Total reliability } & $\mathbf{0 . 6 8}$ & $\mathbf{3 . 5 5}$ & - \\
\hline
\end{tabular}

Table (4) clarifies that the dimensions of training needs based reciprocal teaching for English language teachers in Asseerincluded(3) dimensions. They are 
respectively arranged according to their mean: (Evaluation skill, Lesson planning skill, Lesson implementation skill. All items came with a "high" training need level; Mean of these dimensions ranged between $(3.52,3.60)$; These are values in the fourth category of the five-step scale, which indicates a degree of training need (high).The general mean of the dimensions is $(3.55,5.0)$, with a standard deviation (0.68), and this indicates that there is a high degree of agreement among participants on the training needs based reciprocal teaching among English language teachers at secondary school in the southern region, where the skill of "evaluation" comes the first skill with an overall mean (3.60) and a standard deviation (0.73),followed by the skill of "lesson planning" with mean (3.52) and standard deviation (0.75).

Finally, the skill of "lesson implementation" which comes as the least teaching skills as ateaching need among English language teachers at secondary school with amean (3.52) and a standard deviation (0.77). This may be due to the importance of educational training in enhancing teachers'skills and competencies related to reciprocal teaching

The following tables discuss -in some detail- the training needs based on reciprocal teaching for secondary school English language teachers in the southern region; as follows:

\section{Training needs of English language teachers related to lesson planning skill}

To determine the training needs of English language teachers related to lesson planning skill; Frequencies, percentages, mean and standard deviation were used for the participants'responses, and the items were arranged according to arithmetic mean for each of them, as follows: 
Table (5):Frequencies, percentages, mean and standard deviation of participants' responses about the training needs of English languageteachers related to lesson planning skill

\begin{tabular}{|c|c|c|c|c|c|c|c|c|c|c|c|c|c|c|}
\hline \multirow{3}{*}{$\mathbf{N}$} & \multirow{3}{*}{ Items } & \multicolumn{10}{|c|}{ Degree of need } & \multirow{3}{*}{ M } & \multirow{3}{*}{ S.D } & \multirow{3}{*}{ Rank } \\
\hline & & \multicolumn{2}{|c|}{ very high } & \multicolumn{2}{|c|}{ high } & \multicolumn{2}{|c|}{ moderate } & \multicolumn{2}{|c|}{ low } & \multicolumn{2}{|c|}{ Very low } & & & \\
\hline & & $\mathbf{F}$ & $\%$ & $\mathbf{F}$ & $\%$ & $\mathbf{F}$ & $\%$ & $\mathbf{F}$ & $\%$ & $\mathbf{F}$ & $\%$ & & & \\
\hline 1 & $\begin{array}{l}\text { Determining } \\
\text { learning outcomes } \\
\text { for teaching English } \\
\text { in specific and } \\
\text { measurable terms. }\end{array}$ & 122 & 38.7 & 126 & 40.0 & 52 & 16.5 & 12 & 3.8 & 3 & 1.0 & 4.12 & 0.88 & 1 \\
\hline 3 & $\begin{array}{l}\text { Determining } \\
\text { educational } \\
\text { methods that are } \\
\text { appropriate for } \\
\text { reciprocal teaching. }\end{array}$ & 64 & 20.3 & 104 & 33.0 & 97 & 30.8 & 45 & 14.3 & 5 & 1.6 & 3.56 & 1.02 & 2 \\
\hline 2 & $\begin{array}{l}\text { Determining stages } \\
\text { of reciprocal } \\
\text { teaching. }\end{array}$ & 42 & 13.3 & 133 & 42.2 & 100 & 31.7 & 36 & 11.4 & 4 & 1.3 & 3.55 & 0.91 & 3 \\
\hline 6 & $\begin{array}{l}\text { Designing } \\
\text { evaluation methods } \\
\text { to take into account } \\
\text { learner differences. }\end{array}$ & 52 & 16.5 & 105 & 33.3 & 118 & 37.5 & 35 & 11.1 & 5 & 1.6 & 3.52 & 0.95 & 4 \\
\hline 4 & $\begin{array}{l}\text { Determining } \\
\text { methods for } \\
\text { preparation to } \\
\text { reciprocal learning } \\
\text { appropriately. }\end{array}$ & 50 & 15.9 & 110 & 34.9 & 115 & 36.5 & 32 & 10.2 & 8 & 2.5 & 3.51 & 0.96 & 5 \\
\hline 12 & $\begin{array}{l}\text { Determining the } \\
\text { roles, groups and } \\
\text { procedures for } \\
\text { reciprocal teaching } \\
\text { appropriately. }\end{array}$ & 65 & 20.6 & 96 & 30.5 & 101 & 32.1 & 42 & 13.3 & 11 & 3.5 & 3.51 & 1.07 & 6 \\
\hline 8 & $\begin{array}{l}\text { Identifying the basic } \\
\text { skills and concepts } \\
\text { of reciprocal } \\
\text { teaching in the } \\
\text { lesson. }\end{array}$ & 60 & 19.0 & 96 & 30.5 & 112 & 35.6 & 34 & 10.8 & 13 & 4.1 & 3.50 & 1.05 & 7 \\
\hline 7 & $\begin{array}{l}\text { Determining the } \\
\text { remedial activities } \\
\text { for reciprocal } \\
\text { teaching during } \\
\text { lesson planning. }\end{array}$ & 60 & 19.0 & 87 & 27.6 & 117 & 37.1 & 41 & 13.0 & 10 & 3.2 & 3.46 & 1.04 & 8 \\
\hline 9 & $\begin{array}{l}\text { Employing } \\
\text { reciprocal teaching } \\
\text { skills in developing } \\
\text { English self- } \\
\text { learning. }\end{array}$ & 60 & 19.0 & 84 & 26.7 & 115 & 36.5 & 46 & 14.6 & 10 & 3.2 & 3.44 & 1.06 & 9 \\
\hline 11 & $\begin{array}{l}\text { bridging learning in } \\
\text { classroom to } \\
\text { students' past and } \\
\text { subsequent } \\
\text { experiences and } \\
\text { interests. }\end{array}$ & 54 & 17.1 & 96 & 30.5 & 110 & 34.9 & 42 & 13.3 & 13 & 4.1 & 3.43 & 1.05 & 10 \\
\hline 5 & $\begin{array}{l}\text { Identifying flexible } \\
\text { and enriching } \\
\text { activities that } \\
\text { develop students' } \\
\text { motivation for } \\
\text { reciprocal learning. }\end{array}$ & 58 & 18.4 & 89 & 28.3 & 112 & 35.6 & 44 & 14.0 & 12 & 3.8 & 3.43 & 1.06 & 11 \\
\hline 10 & $\begin{array}{l}\text { Teacher's focus in } \\
\text { his planning of } \\
\text { reciprocal teaching } \\
\text { on developing } \\
\text { English language } \\
\text { skills. }\end{array}$ & 52 & 16.5 & 93 & 29.5 & 114 & 36.2 & 49 & 15.6 & 7 & 2.2 & 3.43 & 1.01 & 12 \\
\hline 13 & $\begin{array}{l}\text { Determining the } \\
\text { appropriate time } \\
\text { for all steps of } \\
\text { reciprocal teaching. }\end{array}$ & 58 & 18.4 & 69 & 21.9 & 122 & 38.7 & 59 & 18.7 & 7 & 2.2 & 3.36 & 1.05 & 13 \\
\hline & & & & nera & lean & & & & & & & 3.52 & 0.75 & - \\
\hline
\end{tabular}


Table (5) clarifies that the dimensions of training needs for English language teachers related to "lesson planning"skill consists of (13) items. (12) itemscame with a "high" training need level, while one item came with a (moderate) training need which is (13). Mean of the dimensionitems ranged between $(3.36,4.12)$. The previous result indicates that participants' responsesto the items of training need degree range from (medium high). The standard deviation of items ranged between (0.88 and 1.07). They are values near around "one", and this indicates the homogeneity of participants' responses on the items of this dimension of training needs of English language teachers related to the skill of "lesson planning".

The general mean for the dimension items was (3.52) with a standard deviation (0.75), and this indicates that there is a high degree of agreement among participants on the training needs of English language teachers related to lesson planning skill, and among the most prominent of these skills (Determining learning outcomes for teaching the English language in specific and measurable terms, as well as identifying educational methods that are appropriate for reciprocal teaching, in addition to identifying steps for implement -ing reciprocal teaching of an English language lesson, and designing evaluation methods in a manner that takes into account learner differences between students).

\section{Lesson implementation skill}

To determine the training needs of English language teachers related to lesson implementation skill; Frequencies, percentages, mean and standard deviation were used for the participants' responses, and the items were arranged according to arithmetic mean for each of them, as follows: 
Table (6):Frequencies, percentages, mean and standard deviation of participants' responses about the training needs of English language teachers related to implementation lesson skill

\begin{tabular}{|c|c|c|c|c|c|c|c|c|c|c|c|c|c|c|}
\hline \multirow{3}{*}{$\mathbf{N}$} & \multirow{3}{*}{ Items } & \multicolumn{10}{|c|}{ Degree of need } & \multirow{3}{*}{$M$} & \multirow{3}{*}{ S.D } & \multirow{3}{*}{ Rank } \\
\hline & & \multicolumn{2}{|c|}{ very high } & \multicolumn{2}{|l|}{ high } & \multicolumn{2}{|c|}{ moderate } & \multicolumn{2}{|l|}{ low } & \multicolumn{2}{|c|}{ Very low } & & & \\
\hline & & $F$ & $\%$ & $\mathbf{F}$ & $\%$ & $F$ & $\%$ & $\mathbf{F}$ & $\%$ & $\mathbf{F}$ & $\%$ & & & \\
\hline 1 & $\begin{array}{l}\text { Preparing the } \\
\text { lesson in an } \\
\text { interesting and } \\
\text { effective way. }\end{array}$ & 116 & 36.8 & 99 & 31.4 & 81 & 25.7 & 16 & 5.1 & 3 & 1.0 & 3.98 & 0.96 & 1 \\
\hline 5 & $\begin{array}{l}\text { Creating exciting } \\
\text { questions for } \\
\text { students that } \\
\text { make them in the } \\
\text { process of } \\
\text { continuous } \\
\text { thinking during the } \\
\text { lesson. }\end{array}$ & 77 & 24.4 & 98 & 31.1 & 93 & 29.5 & 35 & 11.1 & 12 & 3.8 & 3.61 & 1.09 & 2 \\
\hline 13 & $\begin{array}{l}\text { Determining the } \\
\text { relationship } \\
\text { between the } \\
\text { components of the } \\
\text { lesson and its title. }\end{array}$ & 64 & 20.3 & 106 & 33.7 & 98 & 31.1 & 39 & 12.4 & 8 & 2.5 & 3.57 & 1.03 & 3 \\
\hline 3 & \begin{tabular}{|l|} 
Dividing students \\
into groups, taking \\
into account \\
learner \\
differences. \\
\end{tabular} & 57 & 18.1 & 119 & 37.8 & 93 & 29.5 & 31 & 9.8 & 15 & 4.8 & 3.55 & 1.05 & 4 \\
\hline 15 & $\begin{array}{l}\text { Clarifying the main } \\
\text { idea of the topic. }\end{array}$ & 58 & 18.4 & 110 & 34.9 & 96 & 30.5 & 45 & 14.3 & 6 & 1.9 & 3.54 & 1.01 & 5 \\
\hline 9 & $\begin{array}{l}\text { Thinking of all } \\
\text { possible questions } \\
\text { on the topic to be } \\
\text { taught. }\end{array}$ & 59 & 18.7 & 106 & 33.7 & 102 & 32.4 & 39 & 12.4 & 9 & 2.9 & 3.53 & 1.02 & 6 \\
\hline 17 & $\begin{array}{l}\text { Identifying the } \\
\text { important } \\
\text { elements of the } \\
\text { topic. }\end{array}$ & 64 & 20.3 & 97 & 30.8 & 103 & 32.7 & 45 & 14.3 & 6 & 1.9 & 3.53 & 1.03 & 7 \\
\hline 21 & $\begin{array}{l}\text { Encouraging } \\
\text { students to group- } \\
\text { work to complete } \\
\text { tasks. }\end{array}$ & 68 & 21.6 & 81 & 25.7 & 117 & 37.1 & 46 & 14.6 & 3 & 1.0 & 3.52 & 1.02 & 8 \\
\hline 22 & $\begin{array}{l}\text { Developing } \\
\text { students' } \\
\text { discussion skills. } \\
\end{array}$ & 61 & 19.4 & 99 & 31.4 & 106 & 33.7 & 42 & 13.3 & 7 & 2.2 & 3.52 & 1.02 & $8^{*}$ \\
\hline 19 & $\begin{array}{l}\text { Reforming the text } \\
\text { in the students' } \\
\text { own style. }\end{array}$ & 65 & 20.6 & 93 & 29.5 & 103 & 32.7 & 49 & 15.6 & 5 & 1.6 & 3.52 & 1.04 & 10 \\
\hline 8 & $\begin{array}{l}\text { Formulating } \\
\text { hypotheses } \\
\text { related to the field } \\
\text { of reciprocal } \\
\text { teaching. } \\
\end{array}$ & 60 & 19.0 & 99 & 31.4 & 104 & 33.0 & 45 & 14.3 & 7 & 2.2 & 3.51 & 1.03 & 11 \\
\hline 11 & $\begin{array}{l}\text { Applying all the } \\
\text { knowledge and } \\
\text { information that } \\
\text { students have in } \\
\text { order to answer } \\
\text { these questions. }\end{array}$ & 55 & 17.5 & 107 & 34.0 & 101 & 32.1 & 46 & 14.6 & 6 & 1.9 & 3.50 & 1.00 & 12 \\
\hline 7 & $\begin{array}{l}\text { Registering } \\
\text { student } \\
\text { expectations on } \\
\text { the subject of the } \\
\text { lesson. }\end{array}$ & 47 & 14.9 & 121 & 38.4 & 102 & 32.4 & 32 & 10.2 & 13 & 4.1 & 3.50 & 1.00 & $12^{*}$ \\
\hline 20 & \begin{tabular}{|l|} 
Motivating \\
students to \\
continuous self- \\
learning of the \\
English language. \\
\end{tabular} & 55 & 17.5 & 104 & 33.0 & 109 & 34.6 & 37 & 11.7 & 10 & 3.2 & 3.50 & 1.01 & 14 \\
\hline 23 & $\begin{array}{l}\text { Encouraging } \\
\text { students to speak }\end{array}$ & 56 & 17.8 & 90 & 28.6 & 125 & 39.7 & 41 & 13.0 & 3 & 1.0 & 3.49 & 0.96 & 15 \\
\hline
\end{tabular}




\begin{tabular}{|c|c|c|c|c|c|c|c|c|c|c|c|c|c|c|}
\hline & fluently in English. & & & & & & & & & & & & & \\
\hline 18 & $\begin{array}{l}\text { Defining sub- } \\
\text { elements in the } \\
\text { topic. }\end{array}$ & 53 & 16.8 & 103 & 32.7 & 111 & 35.2 & 40 & 12.7 & 8 & 2.5 & 3.49 & 1.00 & 16 \\
\hline 16 & $\begin{array}{l}\text { Determining what } \\
\text { may be a } \\
\text { hindrance to } \\
\text { understanding the } \\
\text { information in the } \\
\text { lesson. }\end{array}$ & 61 & 19.4 & 92 & 29.2 & 107 & 34.0 & 47 & 14.9 & 8 & 2.5 & 3.48 & 1.04 & 17 \\
\hline 12 & $\begin{array}{l}\text { Defining and } \\
\text { distributing } \\
\text { groups, roles and } \\
\text { tasks } \\
\text { appropriately and } \\
\text { effectively. }\end{array}$ & 62 & 19.7 & 89 & 28.3 & 113 & 35.9 & 39 & 12.4 & 12 & 3.8 & 3.48 & 1.06 & 18 \\
\hline 14 & $\begin{array}{l}\text { Providing } \\
\text { sufficient time to } \\
\text { apply the } \\
\text { procedural steps } \\
\text { for reciprocal } \\
\text { teaching. }\end{array}$ & 56 & 17.8 & 93 & 29.5 & 113 & 35.9 & 45 & 14.3 & 8 & 2.5 & 3.46 & 1.02 & 19 \\
\hline 6 & $\begin{array}{l}\text { Determining the } \\
\text { purpose of } \\
\text { teaching the } \\
\text { subject to be } \\
\text { taught to students. }\end{array}$ & 56 & 17.8 & 96 & 30.5 & 109 & 34.6 & 46 & 14.6 & 8 & 2.5 & 3.46 & 1.03 & 20 \\
\hline 4 & $\begin{array}{l}\text { Providing a } \\
\text { practical model for } \\
\text { students to the } \\
\text { steps of reciprocal } \\
\text { teaching. }\end{array}$ & 50 & 15.9 & 91 & 28.9 & 120 & 38.1 & 48 & 15.2 & 6 & 1.9 & 3.42 & 0.99 & 21 \\
\hline 10 & $\begin{array}{l}\text { Posing questions } \\
\text { directly and } \\
\text { analytically. }\end{array}$ & 55 & 17.5 & 94 & 29.8 & 104 & 33.0 & 50 & 15.9 & 12 & 3.8 & 3.41 & 1.07 & 22 \\
\hline 2 & $\begin{array}{l}\text { Equipping the } \\
\text { classroom } \\
\text { environment } \\
\text { appropriately for } \\
\text { reciprocal teaching } \\
\text { strategy. } \\
\end{array}$ & 34 & 10.8 & 99 & 31.4 & 128 & 40.6 & 49 & 15.6 & 5 & 1.6 & 3.34 & 0.92 & 23 \\
\hline
\end{tabular}

Table (6) clarifies that the dimensions of training needs for English language teachers related to "lesson implementation" skill consists of (23) items. (22) items came with a "high" training need level, while one item came with a (moderate) training need which is (2). Mean of the dimension items ranged between (3.34, 3.98). The previous result indicates that participants' responsesto the items of training need degree range from (medium - high). The standard deviation of items ranged between ( 0.96 and 1.09 ). They are values near around "one", and this indicates the homogeneity of participants' responses on the items of this dimension of training needs of English language teachers related to the skill of "lesson implementation ". The general 
mean for the dimension items was (3.52) with a standard deviation (0.77), and this indicates that there is a high degree of agreement among participants on the training needs of English language teachers related to lesson implementation skill, and among the most prominent of these skills (Preparing the lesson in an interesting and effective way, as well as Creating exciting questions for students that make them in the process of continuous thinking during the lesson, in addition to Determining the relationship between the components of the lesson and its title).

\section{Evaluation skill}

To determine the training needs of English language teachers related to evaluation skill; Frequencies, percentages, mean and standard deviation were used for the participants' responses, and the items were arranged according to arithmetic mean for each of them, as follows:

Table (7) clarifies that the dimensions of training needs for English language teachers related to "Evaluation" skill consists of (9) items. Allitems came with a "high" training need level. Mean of the items ranged between $(3.45,3.94)$. The previous result indicates that participants' responsesto the items of training need degree range from (medium - high). The standard deviation of items ranged between $(0.94$ and 1.02). They are values near around "one", and this indicates the homogeneity of participants' responses on the items of this dimension of training needs of English language teachers related to the skill of "Evaluation ". The general mean for the dimension items was (3.60) with a standard deviation (0.73), and this indicates that there is a high degree of agreement among participants on the training needs of English language teachers 
related to evaluation skill, and among the most prominent of these skills (Providing diverse and exciting questions for higher-order thinking., as well as Evaluating main learning aspects included in the lesson., in addition to Providing appropriate feedback based on evaluation results and Identifying common mistakes among students).

Table (7): Frequencies, percentages, mean and standard deviation of participants' responses about the training needs of English language teachers related toevaluation skill

\begin{tabular}{|c|c|c|c|c|c|c|c|c|c|c|c|c|c|c|}
\hline \multirow{3}{*}{$\mathbf{N}$} & \multirow{3}{*}{ Items } & \multicolumn{10}{|c|}{ Degree of need } & \multirow{3}{*}{ M } & \multirow{3}{*}{ S.D } & \multirow{3}{*}{ Rank } \\
\hline & & \multicolumn{2}{|c|}{ very high } & \multicolumn{2}{|c|}{ high } & \multicolumn{2}{|c|}{ moderate } & \multicolumn{2}{|c|}{ low } & \multicolumn{2}{|c|}{ Very low } & & & \\
\hline & & $\mathrm{F}$ & $\%$ & $\mathbf{F}$ & $\%$ & $\mathbf{F}$ & $\%$ & $\mathbf{F}$ & $\%$ & $\mathbf{F}$ & $\%$ & & & \\
\hline 7 & $\begin{array}{l}\text { Providing diverse } \\
\text { and exciting } \\
\text { questions for } \\
\text { higher-order } \\
\text { thinking. } \\
\end{array}$ & 111 & 35.2 & 106 & 33.7 & 75 & 23.8 & 13 & 4.1 & 10 & 3.2 & 3.94 & 1.02 & 1 \\
\hline 1 & $\begin{array}{l}\text { Evaluating main } \\
\text { learning aspects } \\
\text { included in the } \\
\text { lesson. }\end{array}$ & 57 & 18.1 & 122 & 38.7 & 97 & 30.8 & 33 & 10.5 & 6 & 1.9 & 3.61 & 0.96 & 2 \\
\hline 5 & $\begin{array}{l}\text { Providing } \\
\text { appropriate } \\
\text { feedback based } \\
\text { on evaluation } \\
\text { results. } \\
\end{array}$ & 60 & 19.0 & 107 & 34.0 & 111 & 35.2 & 34 & 10.8 & 3 & 1.0 & 3.59 & 0.95 & 3 \\
\hline 3 & $\begin{array}{l}\text { Identifying } \\
\text { common } \\
\text { mistakes among } \\
\text { students. }\end{array}$ & 57 & 18.1 & 115 & 36.5 & 103 & 32.7 & 36 & 11.4 & 4 & 1.3 & 3.59 & 0.95 & 4 \\
\hline 9 & $\begin{array}{l}\text { Employing } \\
\text { various, } \\
\text { appropriate and } \\
\text { planned tools. }\end{array}$ & 57 & 18.1 & 110 & 34.9 & 106 & 33.7 & 41 & 13.0 & 1 & 0.3 & 3.57 & 0.94 & 5 \\
\hline 6 & $\begin{array}{l}\text { Using clear, } \\
\text { targeted and } \\
\text { logical methods } \\
\text { to evaluate all } \\
\text { students. }\end{array}$ & 62 & 19.7 & 95 & 30.2 & 121 & 38.4 & 32 & 10.2 & 5 & 1.6 & 3.56 & 0.97 & 6 \\
\hline 4 & $\begin{array}{l}\text { Benefiting from } \\
\text { evaluation results } \\
\text { in treating } \\
\text { students' } \\
\text { mistakes. } \\
\end{array}$ & 57 & 18.1 & 113 & 35.9 & 94 & 29.8 & 47 & 14.9 & 4 & 1.3 & 3.55 & 0.99 & 7 \\
\hline 2 & $\begin{array}{lr}\text { Diagnosing } & \text { the } \\
\text { difficulties that } \\
\text { students face } \\
\text { during the lesson. }\end{array}$ & 59 & 18.7 & 98 & 31.1 & 115 & 36.5 & 38 & 12.1 & 5 & 1.6 & 3.53 & 0.98 & 8 \\
\hline 8 & $\begin{array}{l}\text { Helping students } \\
\text { to self-assess } \\
\text { their learning and } \\
\text { their colleagues } \\
\text { objectively. }\end{array}$ & 41 & 13.0 & 111 & 35.2 & 120 & 38.1 & 35 & 11.1 & 8 & 2.5 & 3.45 & 0.94 & 9 \\
\hline & & & & eera & ean & & & & & & & 3.60 & \begin{tabular}{|l|}
0.73 \\
\end{tabular} & - \\
\hline
\end{tabular}


What is the proposed training program based reciprocal teaching for secondary school teachers of English in Asseer?

Through the training needs of secondary school English language teachers in the light of reciprocal teaching skills; The proposed training program was designed in the three dimensions that formed a training need, they are: planning, implementation, and evaluation. The time period for the implementation of the program was set (two days) with eight training hours, and each day contains two training time periods with four training hours (appendix 5). The program was judged and reviewed by the Training and Scholarship Department (Quality and Performance Measurement Department) at the Education Department in Asseer, and some of the experts in the field of curricula and teaching methods. The program included the following procedures:

Title: A Proposed Training Program for Developing Reciprocal Teaching Skills For Secondary School English Language Teachers.

\section{General goal of the program:}

Participant acquires the most important skills needed for reciprocal teaching.

\section{Detailed objectives:}

At the end of the training program, the trainee is expected to be able to:

- Explain the concept of reciprocal teaching strategy.

- clarify the principles of reciprocal teaching strategy.

- Explain the importance of reciprocal teaching strategy.

- Explain the work stages during reciprocal teaching strategy.

- Demonstrates the advantages of reciprocal teaching 
strategy.

- Clarify the characteristics of reciprocal teaching strategy.

- Clarify the necessary criteria of reciprocal teaching strategy.

- Acquire reciprocal teaching strategy skills.

- Recognize the teacher's role in reciprocal teaching strategy.

- Recognize the learner's role in reciprocal teaching strategy.

- Implement detailed procedures for the application of reciprocal teaching in its various stages.

The general principles on which the program is based

The current program is based on:

- Preparing the program in light of the reciprocal teaching skills.

- Paying attention to training needs checklist of English language teachers at secondary school.

- Ensuring the teacher 's (trainee) positivity and activity through his interest in achieving the goals of the program.

- Achieving interaction and participation between the trainer and the teachers.

- Linking past experiences of the trained teachers with the current experiences in teaching reality by encouraging them to perform realistic learning educational tasks.

- Combining different methods of training, such as: self-learning, cooperative learning, etc.

\section{Program components:}

The program components were defined to achieve the previous goals, and it was taken into consideration that the program builds on the knowledge that teachers possess with addition to it, where the trained teacher 
has the knowledge necessary to teach English at secondary school, and the trainer adds training on reciprocal teaching skills.

\section{How to prepare the program:}

In preparing the program, the researcher relied on the theoretical framework and previous studies in reciprocal teaching skills and in-service teacher training programs.

\section{Mechanism of activating the program:}

The program is based on the philosophy of active participation between teachers with each other, and with the researcher, during the acquisition and development of English language teaching skills in light of reciprocal teaching skills.

Techniques used in the program:

- Lecture and group discussion.

- Cooperation: between the researcher and the teachers.

- Comparison.

- Self-evaluation.

- Feedback.

The main strategies in the program:

- Brainstorming.

- Micro-teaching.

- Seminars.

- Lectures.

- Group discussion.

- Practical/field Training.

Teaching aids used in implementing the program:

Teaching aids and tools used in the program vary according to the skill being trained, and what contributes to achieving the goals. These tools include: 
- computer.

- Data Show.

- Training worksheets.

- Power Point.

- colored pens and papers.

- Paperboard Stand.

The foundations that were used in designing the training program:

- Previous research and studies.

- Reciprocal teaching skills.

- Characteristics of building training programs.

- Training needs.

Target groups of the training program:

Secondary School English Language Teachers.

\section{Trainers:}

The program can be carried out by:

- An expert in curricula and teaching methods.

- English Language Supervisor.

\section{Duration of the training program:}

- The number of training days for the program (two days).

- The number of training hours for the program is (8) hours.

- The number of training sessions for the program is 4 .

- Duration of one session (two hours).

\section{Program design:}

The program follows Gerlach and Ely Instructional Design Model as stated by Al-Riyashi (2014) which is best suited to designing the current research program as shown in the following figure: 


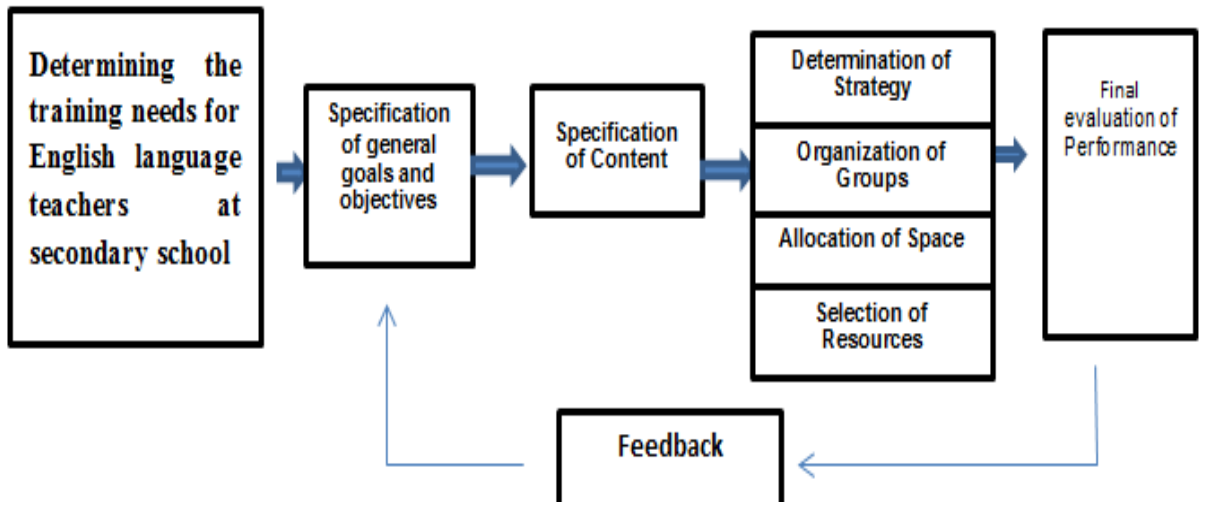

The training period takes two days, with two training sessions a day. Each session takes two hours, as in the Table (8):

\section{Findings:}

\section{The current search findings revealed the following:}

- There is a high degree of agreement among participants on the training needs based on reciprocal teaching among English language teachers at secondary school in the southern region. "Evaluation skill" comes first among reciprocal teaching skills, followed by lesson planning skill, and came last implementation of the lesson skill as the least teaching skills needed for teachers of English at secondary school.

- There is a high degree of agreement among participants on the training needs for teachers of English related to lesson planning skill.

- There is a high degree of agreement among participants on the training needs for teachers of English related to lesson implementation skill.

- There is a high degree of agreement among participants on the training needs for teachers of English related to evaluation skill. 
Table (8) schedule for training program

\begin{tabular}{|c|c|c|c|c|}
\hline Day & Session & Subject & Goals of the unit & time \\
\hline \multirow[b]{2}{*}{ First } & First & $\begin{array}{l}\text { Beginning and opening } \\
\text { the program. } \\
\text { The concept and } \\
\text { principles of reciprocal } \\
\text { teaching. }\end{array}$ & $\begin{array}{l}\text { - Introducing training } \\
\text { procedures. } \\
\text { - Providing information } \\
\text { about training procedures, } \\
\text { goals and steps, the } \\
\text { number of sessions and the } \\
\text { time of each session. } \\
\text { - Introducing the concept } \\
\text { of reciprocal teaching. } \\
\text { - Determine the principles } \\
\text { of reciprocal teaching. }\end{array}$ & $\begin{array}{l}120 \\
\text { mns }\end{array}$ \\
\hline & Second & $\begin{array}{l}\text { - Importance of } \\
\text { reciprocal teaching } \\
\text { strategy. } \\
\text { - Work stages during } \\
\text { reciprocal teaching } \\
\text { strategy. } \\
\text { - Advantages of } \\
\text { reciprocal teaching } \\
\text { strategy. } \\
\text { - Characteristics of } \\
\text { reciprocal teaching } \\
\text { strategy. } \\
\text { - The necessary } \\
\text { criteria of reciprocal } \\
\text { teaching strategy. }\end{array}$ & $\begin{array}{l}\text { - Explain the importance } \\
\text { of reciprocal teaching. } \\
\text { - Explain the work stages } \\
\text { during reciprocal teaching } \\
\text { strategy. } \\
\text { - Demonstrates the } \\
\text { advantages of reciprocal } \\
\text { teaching strategy. } \\
\text { - Clarify the } \\
\text { characteristics of reciprocal } \\
\text { teaching strategy. } \\
\text { - Clarify the necessary } \\
\text { criteria of reciprocal } \\
\text { teaching strategy. }\end{array}$ & $\begin{array}{l}120 \\
\text { mns }\end{array}$ \\
\hline \multirow[t]{2}{*}{ Second } & First & $\begin{array}{l}\text { - Reciprocal teaching } \\
\text { skills. } \\
\text { - Teacher's role in } \\
\text { reciprocal teaching } \\
\text { strategy. } \\
\text { - Learner's role in } \\
\text { reciprocal teaching } \\
\text { strategy. } \\
\text { - Detailed procedures } \\
\text { for the application of } \\
\text { reciprocal teaching in } \\
\text { its various stages. }\end{array}$ & $\begin{array}{l}\text { - DeterminingReciprocal } \\
\text { teaching skills. } \\
\text { - Allocating Teacher's role } \\
\text { in reciprocal teaching } \\
\text { strategy. } \\
\text { - Allocating Learner's role } \\
\text { in reciprocal teaching } \\
\text { strategy. } \\
\text { - Presenting detailed } \\
\text { procedures for the } \\
\text { application of reciprocal } \\
\text { teaching in its various } \\
\text { stages. }\end{array}$ & $\begin{array}{l}120 \\
\text { mns }\end{array}$ \\
\hline & Second & - The closing session & $\begin{array}{l}\text { - The final evaluation of } \\
\text { the trainees. } \\
\text { - Closing the training } \\
\text { program. }\end{array}$ & $\begin{array}{l}120 \\
\text { mns }\end{array}$ \\
\hline \multicolumn{2}{|c|}{$\begin{array}{l}\text { Total days } \\
2 \text { days }\end{array}$} & $\begin{array}{c}\text { Total sessions } \\
4 \text { sessions }\end{array}$ & \multicolumn{2}{|c|}{$\begin{array}{c}\text { Total training hours: } \\
\text { Eight hours of training ( } 480 \text { minutes) }\end{array}$} \\
\hline
\end{tabular}




\section{Recommendation}

In light of the current findings, the research recommends the following:

- Adopting aproposed training program for developing reciprocal teaching skills for secondary school English language teachers within the training plans in the professional development centers of the education departments of Ministry of Education.

- Providing the opportunity to English language teachers to complete postgraduate studies (Master $\mathrm{PhD}$ ) to enhance their skills and teaching capabilities, as the findings showed that all English language teachers at secondary schoolin Asseer have -onlyBachelor's as academic qualification.

- Paying attention to training English language teachers in the secondary stage continuously, through holding courses, training programs and workshops for training in modern strategies and teaching methods that are appropriate for teaching English language.

- Making reciprocal teaching strategy as a partin field education for prospective teachers, which has an effective role in raising the level of professional development and teaching skills of prospective teachers.

- Analyzing the content of the English language at secondary school, in order to gain knowledge about the best teaching methods that suit the content.

- The necessity of taking into consideration the international standards for language teachers in the twenty-first century, in preparing modern training programs to qualify and train English language teachers before and during service. 
- Holding seminars and conferences to discuss the modern and appropriate methods of teaching English by teachers and supervisors.

- Establishing partnerships between education departments, colleges of education, and languages and translation colleges to benefit from studies and research related to teaching English.

\section{References:}

- Abbas, Abdel-Moneim (2007). Planning and designing curricula and training programs. Management Development - Egypt, 115 (26), 40-41.

- Abd al-Samea, Mostafa; Hawala, Suhair (2005). Teacher preparation, development and training. Amman: Dar Al-Fikr.

- Abu Al-Hassan, Talaha Youssef (2016). The professional development needs of mathematics teachers in formal primary schools for languages. Journal of the Egyptian Mathematics Education Association, 19 (4), 62-129.

- Al- Muntashiri, Ali Ahmed Abdullah (2008). The effect of using reciprocal teaching in developing some reading comprehension skills among first grade students. Master Thesis, College of Education, King Khalid University, Kingdom of Saudi Arabia.

- Al-Dahshan, Jamal Ali Khalil (2017). Training needs, definition, importance, and ways of identifying. Arab Studies in Education and Psychology, Association of Arab Educators.

- Al-Harbi, Abdul Karim bin Saji (2012). Determining the training needs of English language teachers in the Qassim region in the field of foreign language teaching. Reading and Knowledge Magazine - Egypt, (130), 78-112.

- Al-Jeaid, Noura Saud (2008). The effectiveness of a proposed training program in the performance of English language supervisors in Taif Governorate and their attitudes towards the profession in light of global developments. PhD thesis, Umm AlQura University, Mecca, Saudi Arabia.

- Al-Lokani, Ahmed Hussein; Al-Jamal, Ali Ahmed (2013). A glossary of educational terms and knowledge in curricula and teaching methods. Cairo: The World of Books.

- Al-Mady, Saad bin Muhammad (2013). A proposed vision for developing teacher education system in the Arab world in light of 
professional standards and requirements, Journal of Culture and Development, Egypt, (67), 45-102.

- Al-Saeed, Saad Muhammad; Saleh, Hoda Mohamed (2008). Training adult education teachers in the Arab world in light of competencies, "a reference guide", the Arab Organization for Education, Culture and Science, Tunisia.

- Al-Sayegh, Muhammad bin Hussain (2002). Teacher selection and preparation in the Kingdom of Saudi Arabia (a future vision). The eleventh conference of the upcoming educational meeting in Riyadh, Kingdom of Saudi Arabia.

- Al-Shaabi, Muhammad (2006). Teaching reading and literature: different strategies for a diverse audience. Cairo: Dar Al-Fikr AlArabi.

- Al-Yasiri, Muhammad (2013). The effect of reciprocal teaching in developing the linguistic ability among fifth literary female students in literature and texts, Master Thesis, College of Education for Humanities, University of Babylon, Iraq.

- Al-Zayyan, Maher Hussein (2013). The effectiveness of a training program for Islamic education teachers to equip them with some skills of improving the Holy Qur'an in the governorates of Gaza. Master Thesis, College of Education, Gaza, Palestine.

- Bayoumi, Yasser Abdel Rahman (2011). The effect of using the reciprocal teaching strategy in developing achievement and attitudes towards mathematics and learning retention among fourth-grade primary students. Journal of Faculty of Education, Tanta University, Egypt, 16 (43), 537-600.

- Kushaitat, Layla (2007). Designing and building training programs. Ministry of Education, Egypt, (45), 80-85.

- Kusumoto, y. (2009). Develop a teacher training program for elementary school homeroom teacher in Japan. University of Hawai,Manoa, Japan.

- Lindblom,C.(2000). Reciprocal teaching from words to meaning. Pacific-Lutheran University, Washington, USA.

- Ministry of Education (2003). The National Standards for Education in Egypt, Volume I, Cairo. Hope for printing and publishing.

- Ostovar,Namaghi and Shahhosseini. (2011). On the effect of reciprocal teaching strategy on EFL learner reading proficiency. journal of language teaching and research, 47(5), 159 - 168. 
- Qadi, ManalAmmar (2014). The Effectiveness of a Proposed Program in the course of Teaching Science methods for Developing Achievement and Teaching Skills and attitudes toward Profession among Female Students. PhD thesis, College of Education, Umm Al-Qura University, Mecca, Saudi Arabia.

- Sulaiman, Salim Abdul Rahman (2010). The effectiveness of a training program for developing reciprocal teaching skills among philosophical subjects teachers during service. Journal of the Educational Association for Social Studies, Egypt, (28), 202-228.

- Sun, L. (2010). A study of effects of reciprocal teaching as a reading strategy instruction on metacognitive awareness, selfefficacy, and English reading comprehension of EFL junior high school students .La Sierra University, California, UAS.

- Tohri, Ali Hadi (2016). A proposed training program for developing numeracy skills among elementary mathematics teachers. Master Thesis, College of Education, King Khalid University, Abha, Saudi Arabia.

- UNESCO Regional Office (2000). Teacher preparation and training: the world of books.

- Zaitoun, Hassan Hussein (2003). Teaching thinking is an applied vision in developing thinking minds. Book World, Cairo. 